\title{
Adrenalectomy for Isolated Metastasis in Five Patients with Lung Cancer: Single Centre Experience and Review of the Literature
}

\author{
Ilkay T. UNEK ${ }^{1}$, Mehmet Ali KOCDOR ${ }^{2}$, A. Ibrahim SEVINC ${ }^{2}$, Ahmet ONEN ${ }^{3}$, Ozhan OZDOGAN ${ }^{4}$, \\ Ilhan OZTOP ${ }^{1}$, Tulay CANDA ${ }^{5}$, Riza CETINGOZ ${ }^{6}$, Berna DEGIRMENCI ${ }^{4}$, Merih G. DURAK $^{5}$, \\ Duygu GUREL ${ }^{5}$, Aydanur KARGI ${ }^{5}$, Omer HARMANCIOGLU², Ugur YILMAZ ${ }^{1}$ \\ ${ }^{1}$ Dokuz Eylul University Faculty of Medicine, Department of Internal Medicine, Division of Medical Oncology \\ ${ }^{2}$ Dokuz Eylul University Faculty of Medicine, Department of General Surgery \\ ${ }^{3}$ Dokuz Eylul University Faculty of Medicine, Department of Thoracic Surgery \\ ${ }^{4}$ Dokuz Eylul University Faculty of Medicine, Department of Nucleer Medicine \\ ${ }^{5}$ Dokuz Eylul University Faculty of Medicine, Department of Pathology \\ ${ }^{6}$ Dokuz Eylul University Faculty of Medicine, Department of Radiation Oncology, Izmir, TURKEY
}

\begin{abstract}
Isolated adrenal metastasis from non-small cell lung cancer (NSCLC) is a rare event. Nonsurgical treatment of a solitary adrenal metastasis is associated with poor survival. However, in the aspect of long-term survival, the role of adrenalectomy for isolated metastasis is unclear. Here, we reported our experience with surgical treatment of solitary adrenal metastasis in patients with NSCLC whose primary tumor control were achieved and reviewed current literature. Between the 2001 and 2009, five patients underwent curative adrenalectomy (in 1 patient it was bilateral) for suspected solitary adrenal metastasis after surgical treatment of NSCLC. The pathologic examination confirmed in 3 cases a NSCLC metastasis while in 2 cases it was a benign lesion. In the follow-up period, all of the 3 patients with adrenal metastasis had recurrence of NSCLC. Recurrence was local (in the operated adrenal bed) in 2 patients. Palliative radiotherapy focalized to adrenal bed was given to one of the patient with local recurrence. This patient is currently alive 51 months after the adrenalectomy. The other patient with local recurrence died 24 months after the adrenalectomy. Recurrence was systemic (brain and contralateral adrenal gland) in 1 patient who was treated with contralateral adrenalectomy and surgical resection of the cranial metastasis followed by cranial radiotherapy. The patient who underwent bilateral adrenalectomy for metastatic lung cancer died of wide-spread metastatic disease, 79 months after the adrenalectomy. In conclusion, survival benefit can be obtained after complete resection of isolated adrenal metastasis in patients with NSCLC. Therefore, resection of isolated adrenal metastasis should be considered if the primary NSCLC is resectable.
\end{abstract}

Keywords: Adrenalectomy, Lung cancer, Solitary adrenal metastasis 


\section{İzole Sürrenal Metastazlı Beş Akciğer Kanseri Olgusunda Adrenalektomi: Tek Merkez Deneyimi} ve Literatürün Gözden Geçirilmesi

Küçük hücreli dışı akciğer kanserinin (KHDAK) izole adrenal metastazı nadir görülür. Soliter adrenal metastazın cerrahi dışı tedavi yöntemlerinde sağkalım kısadır. Bununla beraber, uzun sağkalım açısından, izole adrenal metastazda adrenalektominin rolü net değildir. Burada, primer tümör kontrolü sağlanmış ve soliter adrenal metastazı cerrahi ile tedavi edilmiş KHDAK hastalarındaki deneyimimiz sunuldu ve güncel literatür derlemesi yapıldı. Soliter adrenal metastazı şüphesiyle, 2001-2009 yılları arasında beş hastaya, KHDAK cerrahi tedavisi sonrası küratif adrenalektomi (bir hastada bilateral adrenalektomi) operasyonu yapıldı. Patolojik inceleme sonucunda, 3 olguda KHDAK metastazı saptanırken, 2 olguda benign lezyon saptandı. İzlemde, adrenalektomiyle adrenal metastazı kanıtlanmış 3 hastanın hepsinde KHDAK rekürrensi oldu. Rekürrens, 2 hastada lokal (opere edilmiş adrenal yatak) idi. Lokal rekürrensli hastaların birine adrenal yatağa yönelik palyatif radyoterapi verildi. Bu hasta adrenalektomiden 51 ay sonrasında olmak üzere hala hayattadır. Lokal rekürrensli diğer hasta, adrenalektomiden 24 ay sonrasında ex oldu. Rekürrens 1 hastada sistemikti (beyin ve kontralateral adrenal bez), bu hasta kontralateral adrenalektomi ve beyin metastazına yönelik cerrahi rezeksiyon ardından kraniyal radyoterapi ile tedavi edildi. Metastatik akciğer kanseri nedeniyle bilateral adrenalektomi operasyonu yapılan hasta, adrenalektomiden 79 ay sonrasında yaygın hastalık ile ex oldu. Sonuç olarak, KHDAK hastalarında izole adrenal metastazın tam cerrahi rezeksiyonu ile sağkalım avantajı elde edilebilir. Bu nedenle, primer KHDAK rezektabl ise, izole adrenal metastazın rezeksiyonu dikkate alınmalıdır.

Anahtar Kelimeler: Adrenalektomi, Akciğer kanseri, Soliter adrenal metastaz

\section{INTRODUCTION}

The adrenal gland is a frequent site for metastasis from lung carcinoma. In patients with non-small cell carcinoma (NSCLC), the occurrence of adrenal metastasis is usually accompanied by metastasis in other organs. ${ }^{1}$ The incidence of solitary adrenal metastasis from NSCLC is low, it was evaluated in 2 prospective studies to be only $1.6 \%$, and $3.5 \% .^{1,2}$ Surgical treatment for metastatic lesions from lung cancer is seldom performed. The detection of adrenal metastasis usually is indicative of advanced disease stage at which a nonoperative treatment usually is used. ${ }^{2} \mathrm{Be}-$ cause of the low incidence of isolated adrenal metastasis, there is limited understanding of the efficacy of adrenal resection. ${ }^{3}$ Several long-term survivors after surgical resection for a solitary adrenal metastasis from NSCLC have been reported in case reports and case series with a small number of patients. ${ }^{2,4-29}$ Herein, we report five patients of NSCLC with a suspected solitary adrenal metastasis treated surgically. The pathologic examination confirmed in 3 cases a NSCLC metastasis. In contrast to the expected short survival in lung cancer with distant metastasis, they achieved prolonged survival after combined treatment regimens. These cases were presented and current literature was reviewed.

\section{PATIENTS AND METHODS}

Between the 2001 and 2009, five patients of 48-71 years of age with operated NSCLC were found to ha- ve an isolated adrenal mass. In two patients (Patients No.1 and 2), the presentation of solitary adrenal masses was synchronous, in remaining three patients, the presentation of adrenal masses was metachronous. After an extensive workup to exclude metastasis to other sites, all adrenal masses that were compatible with an isolated adrenal metastasis were completely resected. We did not perform any fine needle aspiration of adrenal masses. In all patients who were accepted for curative adrenalectomy, the primary NSCLC had been treated by complete surgical resection and systematic nodal dissection. In one patient (Patient No.4), mediastinoscopy was performed prior to lung resection. Only one patient (Patient No.2) had systematically received preoperative platinumbased chemotherapy, three patients received postoperative platinum-based chemotherapy. The remaining patient (Patient No.5) did not receive adjuvant chemotherapy. Radiation therapy of the mediastinum was given to two patients (Patient No.4 and 5). Patient No.3 received adjuvant radiotherapy focalized on primary tumor bed.

In all patients, subcostal transverse laparatomy was chosen for adrenal surgery and a wide surgical exposure was obtained. The macroscopic adjacent organ invasion was not observed in any of patients. Metastatic adrenal gland was resected carefully with surrounding tissue and care was taken to avoid capsular injury. Curative resection rendering the patient free of disease was possible and surgical margins were negative in all patients. However, tumor invaded the 
adrenal capsule in 2 patients. All patients presenting with local recurrences had capsular invasion of the adrenal gland on histologic examination. There were no perioperative deaths or postoperative complications. Prior or after adrenalectomy, no particular criteria were defined to give any neoadjuvant/adjuvant treatment including radiotherapy focalized on adrenal bed, or platinum-based chemotherapy protocols. Decisions for complementary treatment were made on a case-by-case basis. We defined a disease-free interval (DFI) corresponding to the time interval between the surgical treatment of the primary tumor and the diagnosis of the adrenal metastasis. In patients with synchronous adrenal masses, the DFI was defined as zero. For a patient with multiple episodes of adrenalectomy, DFI was calculated from the diagnosis date of the first adrenal metastasis. Disease-free survival (DFS) was defined as the time interval from the adrenalectomy to the date of disease recurrence. Survival was calculated from the date of adrenalectomy to death or the date of last follow-up. All the patients underwent a strict follow-up every 3 months. Survival curve of the reported lung cancer patients who underwent adrenalectomy for solitary adrenal metastasis was estimated by the Kaplan-Meier method.

\section{RESULTS}

The characteristics and clinical outcomes of these patients are outlined in Table 1.

In patient No.1, the imaging techniques [computed tomography (CT) and magnetic resonance imaging (MRI)] could not be sufficient to determine whether the lesion represents a metastasis or an adenoma. He underwent left adrenalectomy for suspected synchronous solitary adrenal metastasis from NSCLC. But the histologic findings confirmed the diagnosis of adrenocortical hyperplasia. Patient No.2, underwent integrated positron emission tomography (PET) with fluorine-18 fluorodeoxyglucose (18F-FDG)-CT (PET-CT). Pathologic 18F-FDG uptake was found in the primary tumor localized at right upper lobe of the lung, mediastinal lymph nodes and left adrenal mass. Clinical staging showed stage IV (T2N2M1) disease. She received six cycles of combination neoadjuvant chemotherapy consisting of cisplatin $75 \mathrm{mg} / \mathrm{m}^{2}$ and docetaxel $75 \mathrm{mg} / \mathrm{m}^{2}$, on day 1, every 21 days. A prominent metabolic response in primary tumor was ob- tained on the PET-CT evaluation after 6 cycles of chemotherapy. The findings in the left adrenal gland were constant and compatible with an adrenal metastasis. Another 3 cycles of the same chemotherapy regimen and 3 cycles of single agent docetaxel regimen were administered to the patient. Metabolic response of the primary tumor was stable but an increased FDG uptake in left adrenal gland was obtained when comparing with the prior PET-CT evaluation. After then, she underwent lung resection and left adrenal gland resection. Interestingly, pathological examination revealed an adenoma of the adrenal gland. Patient No.3, with recurrence in adrenal bed refused the re-operation. Because of the poor performance status (ECOG 3), radiotherapy and chemotherapy were not considered and best supportive care was administered to the patient and he died 12 months after the recurrence. In Patient No.4, an unresectable local recurrence was detected during the intraoperative evaluation and he was treated with palliative radiotherapy (total dose; 45 Grays) focalized on the adrenal bed. This patient is currently alive 44 months after the recurrence. In patient No.5, 18 months after left adrenalectomy, a solitary brain metastasis was detected and surgical resection of the metastasis was performed followed by cranial radiotherapy. Two years after left adrenalectomy, a solid mass of $4 \mathrm{~cm}$ was visualized in the right adrenal gland by CT scan. Following 2 cycles of chemotherapy consisting of carboplatin and gemcitabine, right adrenalectomy was performed and the histopathological study showed metastatic adenocarcinoma. Gefitinib (Iressa ®) 250 $\mathrm{mg}$ tablet was administered to the patient orally once a day for 16 months until the progression. Because of the contralateral lung metastasis and supraclavicular lymph nodes metastases, she received 5 cycles of chemotherapy consisting of docetaxel $75 \mathrm{mg} / \mathrm{m} 2$, on day 1 , every 21 days. Because of the progression, another 7 cycles of chemotherapy with vineralbine $25 \mathrm{mg} / \mathrm{m} 2$, on days 1 and 8 , every 21 days, were administered to the patient. She died of wide-spread metastatic disease in 2009,8 years after initial presentation.

\section{DISCUSSION}

The incidence of adrenal mass in patients with operable NSCLC was reported to range from $4 \%$ to $18 \%$, approximately $60 \%$ of these were benign. ${ }^{1}$ Concer- 


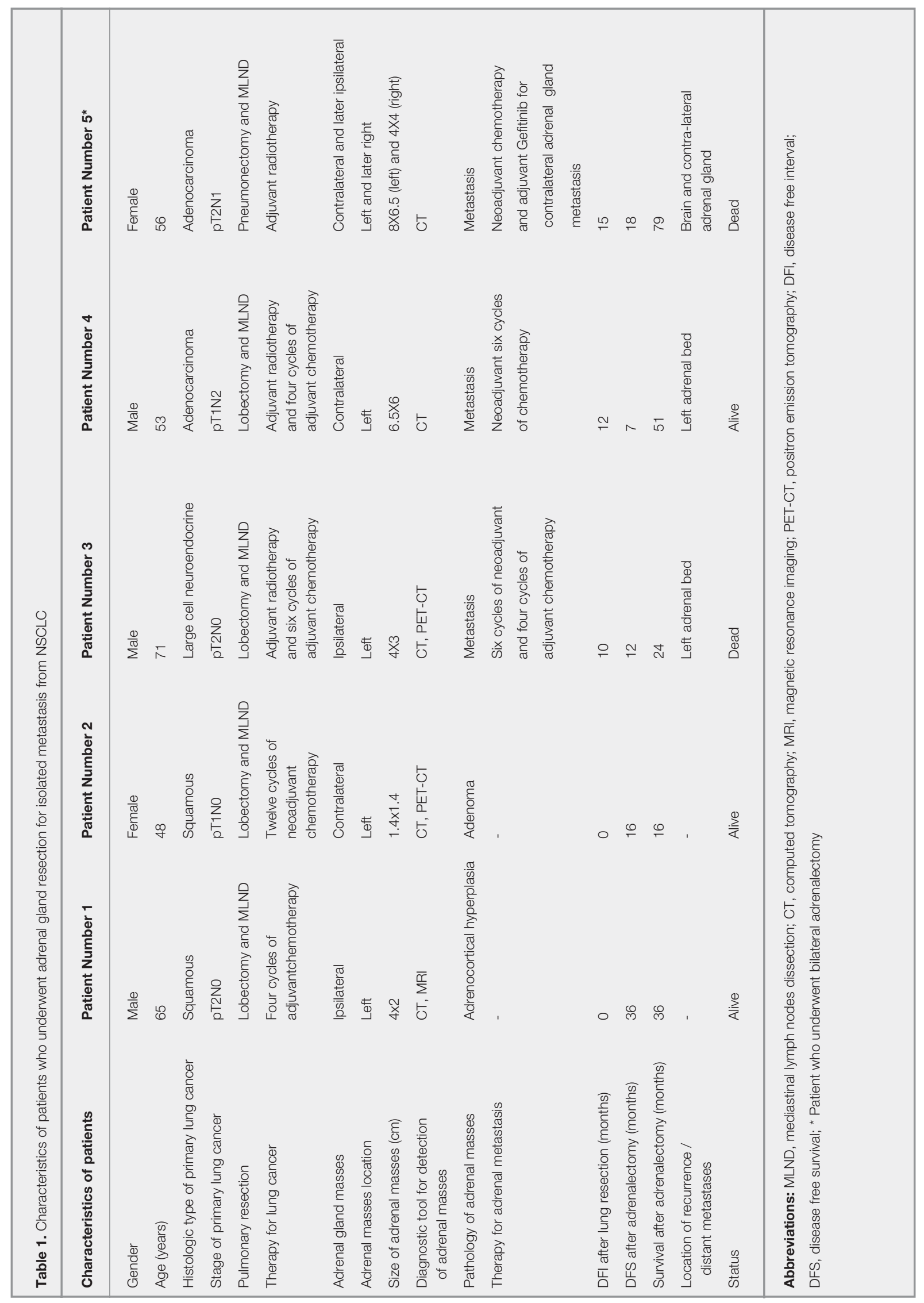


ning the therapeutic management of a solitary adrenal mass from operable NSCLC, the first step is to determine whether it represents a metastasis or an adenoma ${ }^{30}$ With improved imaging and recent techniques, such as contrast medium washout measurement on CT and chemical-shift MRI, only a small proportion of adrenal masses cannot be characterized accurately. ${ }^{31,32}$ The small numbers of masses that remain indeterminate after these investigations, require PET imaging or percutaneous biopsy. In many places the lack of availability of PET presently limits its clinical use. ${ }^{31}$ Metastatic disease involving the adrenal gland has been suggested when these adrenal lesions show changes on serial CT scans. Unfortunately, the determination of benignity or malignancy of adrenal masses by serial CT scans over several months in a cancer patient adds unnecessary delay in the institution of definitive treatment. ${ }^{1.30}$ Therefore, the presence of unilateral adrenal mass in patients with otherwise operable NSCLC should not preclude thoracotomy without pathologic proof of metastatic disease.' Similarly, in a patient of our series (Patient No.1), CT and MRI could not be sufficient to determine whether the lesion in adrenal gland represents a metastasis or an adenoma. PET imaging was not available at that time in our city. The patient eventually underwent surgical resection of the primary tumor followed by adrenalectomy. Fine needle aspiration biopsy (FNAB) under radiological guidance is regarded as a useful tool in resolving these diagnostic problems. ${ }^{33-}$ ${ }^{35}$ It is a relatively safe and effective means of achieving a definitive diagnosis in doubtful cases, however, this procedure may be nondiagnostic or complicated due to anatomic constraints..$^{14,36-40}$ It has been reported that samples could be taken insufficiently, thus resulting in nondiagnostic specimens as frequently as $28 \% .^{37}$ When insufficient material results from a biopsy, repeat aspiration or even the performance of an adrenalectomy should be considered..$^{14,36,39}$ Because of sampling error, there is always a possibility that percutaneous biopsy could yield false-negative diagnoses of malignancy. Therefore, even if the biopsy reveals negative test results, there is stil no guarantee that the adrenal gland is free from malignancy. ${ }^{14,37,39}$ Because of the similarity of the cytologic appearance between normal adrenal cortex and adrenal adenoma, it is essential that the needle be placed correctly in the mass during FNAB to obtain a high degree of accuracy. ${ }^{30}$ Welch and coworkers, re- viewing 277 percutaneous adrenal biopsies, reported an overall accuracy of $90 \%$. The positive predictive value for metastasis was $99 \%$, however, the negative predictive value was approximately $80 \%{ }^{38}$ In patient No.1, left adrenalectomy was performed without histologic confirmation for suspected adrenal metastasis. The size of adrenal mass of this patient was $4 \times 2$ $\mathrm{cm}$. Many studies have suggested that the size of unilateral adrenal mass as seen on a CT scan is an important criterion for differentiating adenomas from metastases ${ }^{30,36}$ Lesions that are $>3 \mathrm{~cm}$ in size are more likely to signify metastases, but benign disease is stil possible ${ }^{30,36}$, as in our patient No. 1. It was reported that, at least for tumors larger than $3.5 \mathrm{~cm}$, biopsy could be avoided and surgical intervention directly performed, regardless of their cytologic appearance by FNAB. ${ }^{14,30}$ Besides, in cases of metachronous metastasis, when imaging examinations performed during follow-up clearly demonstrate the recent occurrence of an adrenal mass, adrenalectomy can be performed without histologic confirmation of the metastasis. ${ }^{2}$ Accordingly, we considered a recent occurrence of adrenal mass during follow-up of our three patients (Patients No.3,4,5) as highly suspected for malignancy so the invasive diagnostic procedures were not needed.

Whole-body FDG PET imaging has proved encouraging in differentiating benign from metastatic adrenal mass in patients with malignancies. ${ }^{41,42}$ It has a better sensitivity, specificity, and accuracy in identifying an adrenal metastasis than MRI or CT scan, with accuracy ranging between $92 \%$ and $100 \%$. 33,44 But, there are stil considerable false-positive and false-negative results on imaging studies. The commonly reported causes of false-positive results have been due to pheochromocytomas and benign adenomas ${ }^{45,46}$ Sung et al. also reported three cases of falsepositive $\mathrm{PET} / \mathrm{CT}$ in patients with lung cancer. ${ }^{47} \mathrm{Kim}$ HK et al. suggest that when adrenal mass is considered benign on CT or PET/CT, surgical resection of NSCLC is indicated, when adrenal mass is indeterminate on CT or PET-CT, histopathological confirmation is needed to determine the nature of adrenal mass. ${ }^{48}$ In a most recent review, the authors states that a PET-positive adrenal lesion, however, should stil undergo biopsy to confirm metastatic disease if this is the sole site of metastasis. ${ }^{49}$ In consistent with this opinion, in one of the our patients (Patient No.2), despite an adrenal mass compatible with metastasis 
on preoperative CT and PET scanning, it was found to have a benign adenoma on postoperative histology. If we had decided not to perform surgical resection of NSCLC in this patient due to malignant findings of imaging studies, she would have lost the opportunity of curative resection even though adrenal mass was benign.

Resection of isolated adrenal metastasis should be considered if the primary NSCLC is resectable..$^{11,15,17}$ Published results of non-surgical therapy demonstrated median survival periods less than 6 and 8.5 months, respectively. ${ }^{8,11}$ There is evidence to believe that adrenalectomy offers good therapeutic results when control of the primary lesion is achieved, and in cases with severe symptoms caused by the adrenal metastasis. ${ }^{6}$ In 1982, Twomey et al. documented prolonged survival after adrenalectomy, along with curative management of the primary cancer in the lung, for patients with clinically isolated adrenal metastasis. ${ }^{4}$ Since then, several similar reports have confirmed the feasibility of this approach. A summary of these case studies (Table 2) demonstrates that selected lung cancer patients with an isolated adrenal metastasis can undergo resection with a reasonable long-term survival., ${ }^{2,-29}$ The median survival of the reported patients calculated with the Kaplan-Meier method was 24 months and the 1-, 2-, 3-, 5-year survival rates were $71.7 \%, 48.4 \%, 38.4 \%, 33.5 \%$, respectively (Figure 1). Luketich and Burt described 14 patients with NSCLC and adrenal metastases, eight of whom were treated with surgical excision and chemotherapy and the other six with chemotherapy alone. ${ }^{11}$ The median survival in the surgical group was significantly greater than that in the chemotherapy group (31 versus 8.5 months; $\mathrm{p}=0.03$ ). The largest series has been published by Porte et al. ${ }^{7}$ Their study included 43 patients between 1987 and 1998 from eight centers. Overall median survival was 11 months, with three patients surviving more than 5 years. It has been stated that surgical treatment of solitary adrenal metastasis from resectable NSCLC could potentially improve survival. ${ }^{17}$ Sarela et al. and Strong et al. reported their laparoscopic adrenalectomy (LA) experience in cancer patients with isolated adrenal gland metastasis from the same center. ${ }^{28,50}$ There were no significant differences in survival when comparing the LA versus open adrenalectomy for NSCLC patients. ${ }^{28,50}$ The median survival of 39 lung cancer patients included in their study was 17

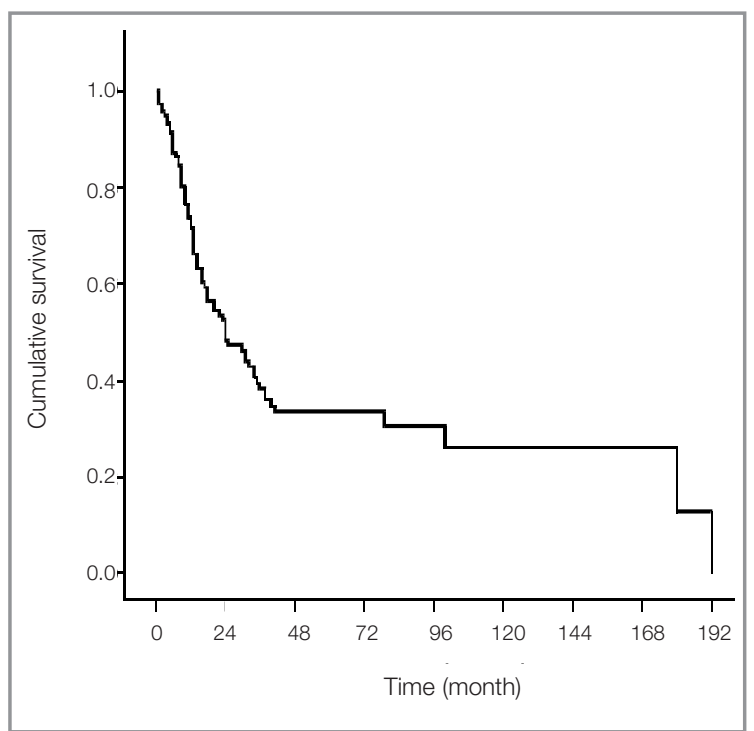

Figure 1. Survival of the reported patients $(n=118)$ after resection of solitary adrenal metastasis from resected NSCLC calculated with the Kaplan-Meier method.

(The patients reported by Lo ${ }^{10}$, Luketich ${ }^{11}$, Kim $^{15}$, Porte $^{17}$, Heniford ${ }^{18}$, Itou $^{26}$, and Strong ${ }^{28}$ were not included in Kaplan-Meier analysis because of the lack of the data on individual survival. Only summarized data are available for these patients).

months. ${ }^{28}$ It was concluded that LA for metastatic adrenal lesions is safe, with equivalent long-term oncological outcomes providing the additional benefits of a minimally invasive technique. ${ }^{28,29,50} \mathrm{~A}$ review compiling reports of 11 articles with 60 patients after resection of adrenal metastases from lung cancer showed a median survival between 14-24 months..$^{51}$ The survival of our series is acceptable, demonstrating that surgical treatment of adrenal metastasis in patients with NSCLC has to be considered. Recently, a summary of patients with metachronous disease were reported by Abdel-Raheem et al. ${ }^{27}$ Overall median survival for patients with adrenalectomy and chemotherapy $(n=8)$ was 19 months and with adrenalectomy alone $(n=5) 14$ months. Therefore, after adrenalectomy, systemic chemotherapy should also be given for possible micrometastatic disease..$^{27,51}$

The rate of local recurrence in 94 patients who underwent adrenalectomy for isolated adrenal metastasis was $17 \% .^{28}$ Of the 94 patients, 39 had NSCLC histology and there were no significant differences in the rate of local recurrence when comparing the NSCLC histology versus all other histologies. ${ }^{28}$ In a 


\begin{tabular}{|c|c|c|c|c|}
\hline $\begin{array}{l}\text { First Author } \\
\text { [Reference] }\end{array}$ & $\begin{array}{l}\text { Year of } \\
\text { Publication }\end{array}$ & $\begin{array}{l}\text { Number of } \\
\text { Patients }\end{array}$ & $\begin{array}{l}\text { Survival Times After } \\
\text { Adrenalectomy (months) }\end{array}$ & $\begin{array}{l}\text { Median Survival After } \\
\text { Adrenalectomy (months) }\end{array}$ \\
\hline Porte $\mathrm{HL}^{2}$ & 1998 & 11 & $4,4,6,8,13,24,66+, 10+, 6,14,6+$ & 6 \\
\hline Twomey $^{4}$ & 1982 & 2 & 180,192 & \\
\hline Raviv $^{5}$ & 1990 & 3 & $35,25,24$ & \\
\hline Reyes $^{6}$ & 1990 & 4 & $36+, 48+, 13,10$ & \\
\hline Kirsch $^{7}$ & 1993 & 1 & $24+$ & \\
\hline Higashiyama $^{8}$ & 1994 & 5 & $40+, 24+, 17,20,9$ & \\
\hline Ayabe $^{9}$ & 1995 & 3 & $108+, 72+, 20$ & \\
\hline $\mathrm{LO}^{10}$ & 1996 & 10 & NA & 13 \\
\hline Luketich $^{11}$ & 1996 & 8 & NA & 31 \\
\hline Urschel $^{12}$ & 1997 & 1 & $108+$ & \\
\hline Wade $^{13}$ & 1998 & 14 & $\begin{array}{l}0.7,0.9,3,5,6,11,11,13 \\
23+, 25+, 32,34,36,61+\end{array}$ & 18 \\
\hline Bendinelli ${ }^{14}$ & 1998 & 4 & $18,9,10+, 8+$ & \\
\hline $\mathrm{Kim}^{15}$ & 1998 & 17 & NA & 14 \\
\hline de Perrot $^{16}$ & 1999 & 1 & $60+$ & \\
\hline Porte $\mathrm{HL}^{17}$ & 2001 & 43 & NA & 11 \\
\hline Heniford $^{18}$ & 1999 & 2 & NA & \\
\hline Bretcha-Boix $^{19}$ & 2000 & 5 & $38,52+, 58+, 16+, 8+$ & \\
\hline Ambrogi $^{20}$ & 2001 & 5 & $66+, 116+, 90+, 30,18$ & \\
\hline Hasan $^{21}$ & 2002 & 1 & 13 & \\
\hline Mercier $^{22}$ & 2005 & 23 & $\begin{array}{l}7,41,100,16,110+, 94+, 6,11,2,16,5,2,9 \\
30+, 8,34,41+, 16,10,13,14+, 9+, 0.3+\end{array}$ & 13.3 \\
\hline Pfannschmidt ${ }^{23}$ & 2005 & 11 & $\begin{array}{l}72+, 10,6,13,9+, 10,12 \\
31,40,31,9\end{array}$ & 12.6 \\
\hline Lucchi $^{24}$ & 2005 & 10 & $18,9,14,80+, 14,12,43+, 38,44+, 37+$ & 18 \\
\hline Muñoz $z^{25}$ & 2006 & 1 & $48+$ & \\
\hline Itou $^{26}$ & 2006 & 6 & NA & 24 \\
\hline Abdel-Raheem ${ }^{27}$ & 2002 & 1 & $10+$ & \\
\hline Strong $^{28}$ & 2007 & 39 & NA & 17 \\
\hline Sebag $^{29}$ & 2006 & 9 & $68+, 66+, 24,24+, 23,22,19+, 1,1+$ & 23 \\
\hline Unek & - & 3 & $24,51+, 79$ & \\
\hline
\end{tabular}




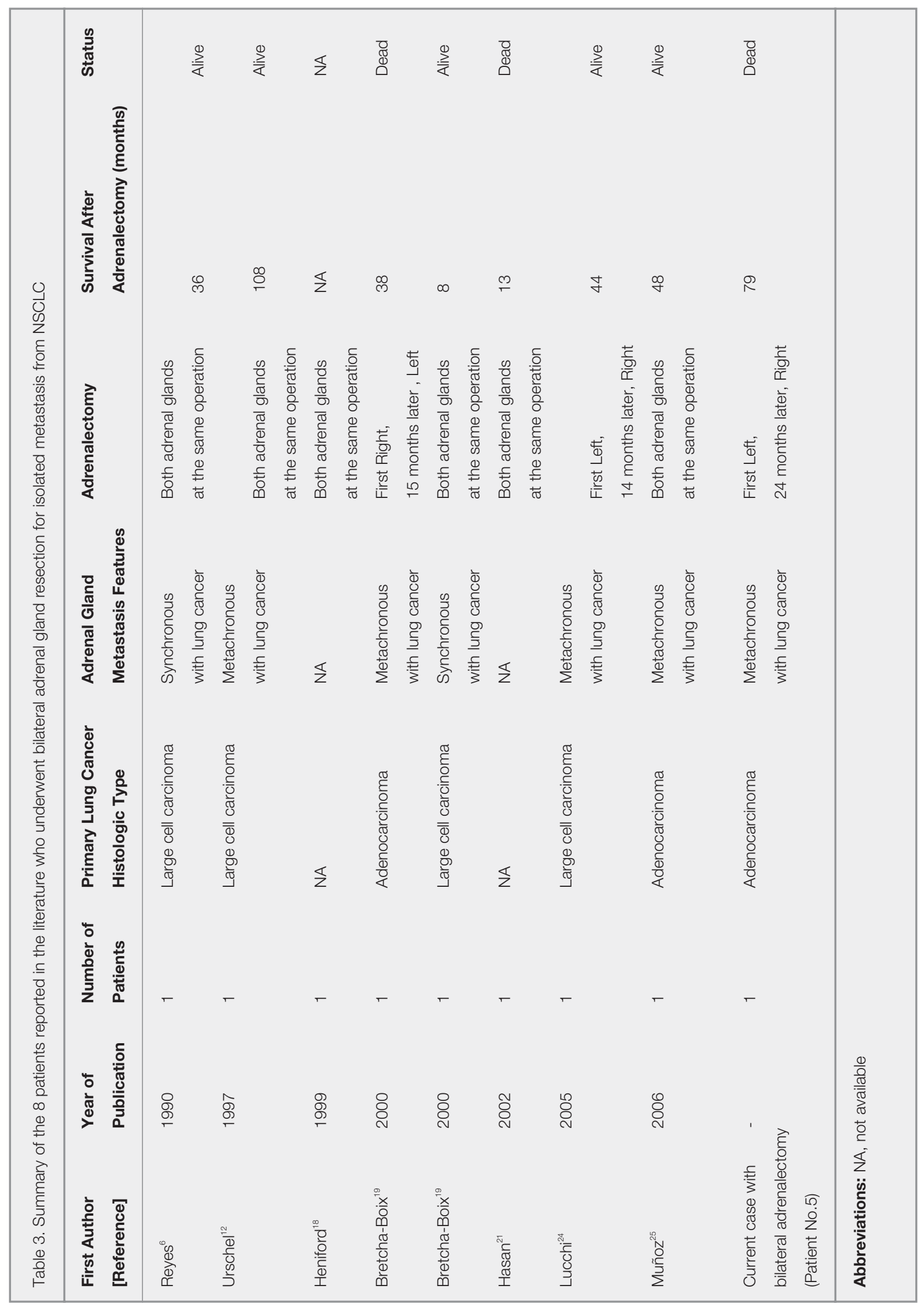


study by Porte et al, seven patients out of 43 NSCLC patients who underwent adrenalectomy, had developed recurrence in the adrenal bed regardless of the surgical approach used. ${ }^{17}$ The authors stated that the recurrences in adrenal bed argues in favor of systematic adjuvant radiotherapy delivered to the adrenal bed. Our three patients with metastatic carcinoma did not receive radiotherapy to the adrenal bed after adrenalectomy. The surgical margins of all the three patients were negative but local recurrenses have developed in two patients with capsular invasion (Patients No.3, 4). However, local recurrence has not developed in the other patient (Patient No.5) without capsular invasion. When our results are taken into account, radiotherapy to the adrenal bed after adrenalectomy may be a reasonable option to prevent the local recurrences in patients with capsular invasion although surgical margins are negative. Randomized prospective trials are needed to evaluate the role of adjuvant radiotherapy to the adrenal bed after adrenalectomy in patients with NSCLC. The rarity of solitary adrenal metastasis makes a randomized prospective trial comparing different treatment regimens unlikely. Surgical resection seems the best option for a potential cure, or at least the best palliative therapy compared to nonsurgical treatments. Accordingly, few reports have been published on the role of radiotherapy on adrenal metastasis. ${ }^{52-54}$ Soffen and colleagues reported the results of palliative radiotherapy in 9 patients with lung carcinoma and isolated adrenal metastasis, whose median survival was 6 months. ${ }^{52}$ Only Miyaji and co-workers reported a case of long-term survival exceeding 34 months after radiotherapy for a metachronous adrenal metastasis, in a patient who underwent resection of the primary NSCLC. ${ }^{54}$

One of the our patients operated on for solitary left adrenal metastasis, developed a right adrenal metastasis and was operated on again. The time interval between these adrenalectomy operations was 2 years. In English medical literature, only 8 cases of bilateral adrenalectomy for metastatic lung cancer were reported. ${ }^{6,12,18,19,21,24,25}$ Table 3, summarizes the data from the literature regarding patients who have undergone potentially curative lung resection and bilateral adrenal resection. In two of the patients, presentation of bilateral adrenal metastases were synchronous with lung cancer ${ }^{6.19}$, in remaining six patients, bilateral adrenal metastases presented metachronously with lung cancer. $^{12,18,19,21,24,25}$ Six of the 8 cases underwent both right and left adrenalectomy at the same operation. ${ }^{6,12,18,19,2,2,25}$ One patient underwent left adrenalectomy for a solitary adrenal gland metastasis and 14 months later, contralateral adrenalectomy for a new solitary metastasis..$^{24}$ The other patient developed recurrent metastases in both adrenals 15 months after right adrenalectomy. ${ }^{19}$ Therefore, he underwent left adrenalectomy and resection of the recurrent lesion in right adrenal bed. Eight months later, the patient were treated by radiosurgery for three metastases in the brain. ${ }^{19}$ Similarly, our patient underwent left adrenalectomy and 2 years later right adrenalectomy. During the time interval between the left and right adrenalectomy operations, she underwent surgical resection of the solitary brain metastasis followed by cranial radiotherapy. As far as we know, a patient with bilateral adrenal metastases who underwent bilateral adrenalectomy and surgical resection of the solitary brain metastasis from lung cancer has not been previously reported. The presence of resected, isolated brain metastasis does not appear to be a contraindication for adrenalectomy. ${ }^{3}$

Some authors suggest that the most appropriate patients for the resection of adrenal gland metastasis are the patients whose disease progresses slowly after lung resection. ${ }^{7.8}$ Accordingly, in some case series, it was found that DFI of less than 6 months and synchronous metastasis were associated with worse survivals. ${ }^{3 ., 15,22,23}$ In contrast to these studies, it was reported that adrenalectomy for synchronous versus metachronous lesions showed no difference in survival. . $^{1728,29}$

In conclusion, survival benefit can be obtained after complete resection of isolated adrenal metastasis in patients with NSCLC. Therefore, resection of isolated adrenal metastasis should be considered if the primary NSCLC is resectable. On the other hand, during preoperative evaluations, the difficulties in differentiating coincidental benign adrenal masses from synchronous metastatic adrenal lesions in patients with lung cancer still continue.

\section{REFERENCES}

1. Ettinghausen SE, Burt ME. Prospective evaluation of unilateral adrenal masses in patients with operable non-small-cell lung cancer. J Clin Oncol 9: 1462-1466, 1991. 
2. Porte HL, Roumilhac D, Graziana JP, et al. Adrenalectomy for a solitary adrenal metastasis from lung cancer. Ann Thorac Surg 65: 331-335, 1998.

3. Tanvetyanon T, Robinson LA, Schell MJ, et al. Outcomes of adrenalectomy for isolated synchronous versus metachronous adrenal metastases in non-small-cell lung cancer: a systematic review and pooled analysis. J Clin Oncol 26: 1142-1147, 2008.

4. Twomey P, Montgomery C, Clark O. Successful treatment of adrenal metastases from large-cell carcinoma of the lung. JAMA 248: 581-583, 1982.

5. Raviv G, Klein E, Yellin A, et al. Surgical treatment of solitary adrenal metastases from lung carcinoma. J Surg Oncol 43: 123-124, 1990.

6. Reyes L, Parvez Z, Nemoto T, et al. Adrenalectomy for adrenal metastasis from lung carcinoma. J Surg Oncol 44: 32-34, 1990.

7. Kirsch AJ, Oz MC, Stoopler M, et al. Operative management of adrenal metastases from lung carcinoma. Urology 42: 716-719, 1993.

8. Higashiyama M, Doi O, Kodama K, et al. Surgical treatment of adrenal metastasis following pulmonary resection for lung cancer: comparison of adrenalectomy with palliative therapy. Int Surg 79: 124-129, 1994.

9. Ayabe $H$, Tsuji $H$, Hara $S$, et al. Surgical management of adrenal metastasis from bronchogenic carcinoma. J Surg Oncol 58: 149-154, 1995.

10. Lo CY, van Heerden JA, Soreide JA, et al. Adrenalectomy for metastatic disease to the adrenal glands. Br J Surg 83: 528-531, 1996.

11. Luketich JD, Burt ME. Does resection of adrenal metastases from non-small cell lung cancer improve survival? Ann Thorac Surg 62: 1614-1616, 1996.

12. Urschel JD, Finley RK, Takita H. Long-term survival after bilateral adrenalectomy for metastatic lung cancer: a case report. Chest 112: 848-850, 1997.

13. Wade TP, Longo WE, Virgo KS, Johnson FE. A comparison of adrenalectomy with other resections for metastatic cancers. Am J Surg 175: 183-186, 1998.

14. Bendinelli C, Lucchi M, Buccianti $P$, et al. Adrenal masses in non-small cell lung carcinoma patients: is there any role for laparoscopic procedures? J Laparoendosc Adv Surg Tech A 8: 119-124, 1998.

15. Kim SH, Brennan MF, Russo P, et al. The role of surgery in the treatment of clinically isolated adrenal metastasis. Cancer 82: 389-394, 1998.

16. de Perrot $M$, Licker $M$, Robert JH, Spiliopoulos A. Long-term survival after surgical resections of bronchogenic carcinoma and adrenal metastasis. Ann Thorac Surg 68: 1084-1085, 1999.

17. Porte H, Siat J, Guibert B, et al. Resection of adrenal metastases from non-small cell lung cancer: a multicenter study. Ann Thorac Surg 71: 981-985, 2001.

18. Heniford BT, Arca MJ, Walsh RM, Gill IS. Laparoscopic adrenalectomy for cancer. Semin Surg Oncol 16: 293-306, 1999.
19. Bretcha-Boix P, Rami-Porta R, Mateu-Navarro M, et al. Surgical treatment of lung cancer with adrenal metastasis. Lung Cancer 27: 101-105, 2000.

20. Ambrogi V, Tonini G, Mineo TC. Prolonged survival after extracranial metastasectomy from synchronous resectable lung cancer. Ann Surg Oncol 8: 663-666, 2001.

21. Hasan R, Harold KL, Matthews BD, et al. Outcomes for laparoscopic bilateral adrenalectomy. J Laparoendosc Adv Surg Tech A 12: 233-236, 2002.

22. Mercier $O$, Fadel E, de Perrot $M$, et al. Surgical treatment of solitary adrenal metastasis from non-small cell lung cancer. J Thorac Cardiovasc Surg 130: 136-140, 2005.

23. Pfannschmidt J, Schlolaut B, Muley T, et al. Adrenalectomy for solitary adrenal metastases from non-small cell lung cancer. Lung Cancer 49: 203-207, 2005.

24. Lucchi $M$, Dini $P$, Ambrogi MC, et al. Metachronous adrenal masses in resected non-small cell lung cancer patients: therapeutic implications of laparoscopic adrenalectomy. Eur J Cardiothorac Surg 27: 753-756, 2005.

25. Muñoz A, López-Vivanco G, Mañé JM, et al. Metastatic non-small-cell lung carcinoma successfully treated with pre-operative chemotherapy and bilateral adrenalectomy. Jpn J Clin Oncol 36: 731-734, 2006.

26. Itou S, Imai T, Usami N, et al. Surgical treatment for adrenal metastasis from lung cancer. Kyobu Geka 59: 47-52, 2006.

27. Abdel-Raheem MM, Potti A, Becker WK, et al. Late adrenal metastasis in operable non-small-cell lung carcinoma. Am J Clin Oncol 25: 81-83, 2002.

28. Strong VE, D'Angelica M, Tang L, et al. Laparoscopic adrenalectomy for isolated adrenal metastasis. Ann Surg Oncol 14: 3392-3400, 2007.

29. Sebag F, Calzolari F, Harding J, et al. Isolated adrenal metastasis: the role of laparoscopic surgery. World J Surg 30: 888-892, 2006.

30. Katz RL, Shirkhoda A. Diagnostic approach to incidental adrenal nodules in the cancer patient. Results of a clinical, radiologic, and fine-needle aspiration study. Cancer 55: 1995-2000, 1985.

31. Sahdev A, Reznek RH. Imaging evaluation of the nonfunctioning indeterminate adrenal mass. Trends Endocrinol Metab 15: 271-276, 2004.

32. Yip L, Tublin ME, Falcone JA, et al. The adrenal mass: Correlation of histopathology with imaging. Ann Surg Oncol 17: 846-852, 2010.

33. Saboorian MH, Katz RL, Charnsangavej C. Fine needle aspiration cytology of primary and metastatic lesions of the adrenal gland. A series of 188 biopsies with radiologic correlation. Acta Cytol 39: 843-851, 1995.

34. Porte HL, Ernst OJ, Delebecq T, et al. Is computed tomography guided biopsy still necessary for the diagnosis of adrenal masses in patients with resectable nonsmall-cell lung cancer? Eur J Cardiothorac Surg 15: 597-601, 1999. 
35. Moreira SG Jr, Pow-Sang JM. Evaluation and management of adrenal masses. Cancer Control 9: 326334, 2002.

36. Silvestri GA, Tanoue LT, Margolis ML, et al. The noninvasive staging of non-small cell lung cancer. Chest 123: 147S-156S, 2003.

37. de Agustín P, López-Ríos F, Alberti N, Pérez-Barrios A. Fine-needle aspiration biopsy of the adrenal glands: A ten-year experience. Diagn Cytopathol 21: 92-97, 1999.

38. Welch TJ, Sheedy PF 2nd, Stephens DH, et al. Percutaneous adrenal biopsy: review of a 10-year experience. Radiology 193: 341-344, 1994.

39. Silverman SG, Mueller PR, Pinkney LP, et al. Predictive value of image-guided adrenal biopsy: analysis of results of 101 biopsies. Radiology 187: 715-718, 1993.

40. Mody MK, Kazerooni EA, Korobkin M. Percutaneous CT-guided biopsy of adrenal masses: immediate and delayed complications. J Comput Assist Tomogr 19: 434-439, 1995.

41. Erasmus JJ, Patz EF Jr, McAdams HP, et al. Evaluation of adrenal masses in patients with bronchogenic carcinoma using 18F-fluorodeoxyglucose positron emission tomography. AJR Am J Roentgenol 168: 1357-1360, 1997.

42. Maurea S, Mainolfi C, Bazzicalupo L, et al. Imaging of adrenal tumors using FDG PET: comparison of benign and malignant lesions. AJR Am J Roentgenol 173: 2529, 1999.

43. Kumar R, Xiu Y, Yu JQ, et al. 18F-FDG PET in evaluation of adrenal lesions in patients with lung cancer. J Nucl Med 45: 2058-2062, 2004.

44. Jana S, Zhang T, Milstein DM, et al. FDG-PET and CT characterization of adrenal lesions in cancer patients. Eur J Nucl Med Mol Imaging 33: 29-35, 2006.

45. Shulkin BL, Thompson NW, Shapiro B, et al. Pheochromocytomas: imaging with 2-[fluorine-18]fluoro-2-deoxy-D-glucose PET. Radiology 212: 35-41, 1999.

46. Yun M, Kim W, Alnafisi N, et al. 18F-FDG PET in characterizing adrenal lesions detected on CT or MRI. J Nucl Med 42: 1795-1799, 2001.

47. Sung YM, Lee KS, Kim BT, et al. (18)F-FDG PET versus (18)F-FDG PET/CT for adrenal gland lesion characterization: a comparison of diagnostic efficacy in lung cancer patients. Korean J Radiol 9: 19-28, 2008.
48. Kim HK, Choi YS, Kim K, et al. Preoperative evaluation of adrenal lesions based on imaging studies and laparoscopic adrenalectomy in patients with otherwise operable lung cancer. Lung Cancer 58: 342-347, 2007.

49. Behzadi A, Ung Y, Lowe $V$, Deschamps C. The role of positron emission tomography in the management of non-small cell lung cancer. Can J Surg 52: 235-242, 2009.

50. Sarela AI, Murphy I, Coit DG, Conlon KCP. Metastasis to the adrenal gland: The emerging role of laparoscopic surgery. Ann Surg Oncol 10: 1191-1196, 2003.

51. Beitler AL, Urschel JD, Velagapudi SR, Takita H. Surgical management of adrenal metastases from lung cancer. J Surg Oncol 69: 54-57, 1998.

52. Soffen EM, Solin LJ, Rubenstein JH, Hanks GE. Palliative radiotherapy for symptomatic adrenal metastases. Cancer 65: 1318-1320, 1990.

53. Short S, Chaturvedi A, Leslie MD. Palliation of symptomatic adrenal gland metastases by radiotherapy. Clin Oncol (R Coll Radiol) 8: 387-389, 1996.

54. Miyaji N, Miki T, Itoh $Y$, et al. Radiotherapy for adrenal gland metastasis from lung cancer: report of three cases. Radiat Med 17: 71-75, 1999.

\section{Correspondence}

Dr. Uğur YILMAZ

Dokuz Eylül Üniversitesi Tıp Fakültesi

İç Hastalıkları Anabilim Dalı

Tıbbi Onkoloji Bilim Dalı

35340, İnciraltı

IZMiR / TURKEY

Tel: (+90.232) 4124801

Fax: (+90.232) 2772303

e-mail: tugba.gun@deu.edu.tr 